\title{
Feedback in College English Writing Based on Computer Automated Scoring System
}

\author{
Xiang Yun \\ School of Foreign Languages \\ Hubei University for Nationalities \\ Enshi, China \\ 52642950@qq.com
}

\begin{abstract}
In English writing instruction, the feedback plays a significant role in students' composition revision and now computer automated scoring system is a trend and applied largely in China. This paper first introduces three feedback, the scoring system and its operating principles, which demonstrate the effects and advantages of this system. Then by reviewing previous researches on feedback, negative and positive effects of each type are shown. Last, some suggestions on incorporation of three feedback are proposed: First, online feedback from automated scoring system can be given first, then peer feedback for students' drafts is followed by teacher feedback from different aspects to provide comments and suggestions. Second, teacher focus on giving concrete suggestions on macro-level of text organization, content and structures, peer students on microlevel of vocabulary and grammar to propose some complementary feedback for the online feedback. Third, in the term of technology, all these steps can be operated online by computer, because Chinese Juku correcting system assisted feedback of three types.
\end{abstract}

Keywords-Feedback; College English Writing; Computer Automated Scoring System

\section{INTRODUCTION TO FEEDBACK}

English writing can reflect the comprehensive ability of students' thinking and language, and this language skill is very important for students in learning and future career. However, compared with other skills, Chinese students' English writing is always their weakness and far from satisfactory. And the teaching of writing has come to assume a much more central position than it was twenty or thirty years ago[1]. However, English teachers in China have to face a large class up to 50 students or even more sometimes. For both teachers and students, the teaching of writing seems the most timeconsuming yet "tedious and unrewarding chore" [2]. To teachers, they involve in too much work in the reading of students' writing but achieve too low efficiency. To students themselves, a lot of time are spend in writing while the effect is not fine. Meanwhile, it is difficult for teachers to offer immediate and full feedback to students' writing. In this traditional product approach of writing, it regards students' writing as a final product, and as "mainly concerned with knowledge about the structure of language, and writing development as mainly the result of the imitation of input, in the form of texts provided by the teacher" [3]. This writing instruction leads students to get limited comments and a few suggestions from teachers only. Even though feedback is valued highly by students and teachers[4], few of them will make revisions, needless to say negotiating with their classmates.

Under the Chinese specific circumstances, the processoriented approaches rooted in L1 writing have been introduced and be widely applied in teaching of writing. A common activity in a process-oriented curriculum is a peer review session, during which students read each other's drafts and make suggestions for revision[5]. They consider the nature of writing as communication and advocate the interaction among the group learners. Brainstorming, planning, drafting, feedback practices, revision, and editing are all the steps in this process. Therefore, peer feedback is valued and can be a complementary part for teacher feedback.

The feedback is a vital step in this process-oriented approach. Feedback, given by Keh[6], is “...input from a reader to a writer with the effect of providing information to the writer for revision". And feedback involves several ones, including teacher feedback, peer feedback and online feedback from automated scoring system in terms of the source of feedback which writers receive. Online feedback from automated scoring system is convenient, quick and detailed as well as targeted. But it still has its weak points, the scoring system and its operating principles will be introduced in the next part.

\section{Automated Scoring System}

In China, with the increasing enrolment of students, English teachers facing a large class calls for a new teaching model involving with multimedia and network technology. For writing evaluation, computer automated scoring system is a trend and applied in a large scale[7].

Automated scoring system treats student's composition as a learner corpus, providing a score, comments and feedback by comparing student's composition with a standard corpus. Each composition is made up of 192 sub-dimensions[8], and the assessing process is like a teacher rating a composition on different aspects with feedback for each sentence to point out the problems in it. When students submit their compositions online, automated scoring system will generate assessing results and feedback for each sentence immediately as shown in Fig. 1 and Fig. 2. These two parts are important for students

It is sponsored by Hubei University for Nationalities (2016JY028). 
in writing and rewriting because students can revise their compositions according to the writing hints and suggestions and then submit again to receive new assessing results and feedback until they achieve best in their essay writing.

\begin{tabular}{|c|c|c|}
\hline \multicolumn{2}{|c|}{$\begin{array}{l}\text { It is excellent in syntax structure, } \\
\text { but more subordinate clauses can } \\
\text { be involved, active words are } \\
\text { applied properly, but it needs some } \\
\text { connecting words to make } \\
\text { sentences fluent. }\end{array}$} & $\begin{array}{l}\text { sub-panel } \\
\text { fast commenting 에 } \\
\text { fast submitting } \\
\text { commenting on text }\end{array}$ \\
\hline Common comments & Revise coms & recommendation \\
\hline \multicolumn{2}{|c|}{ Rank: $8(144)$, the highest score: 85.5 , the lowest score: 31.5} & no similarity, rewriting \\
\hline Rating by teacher & \multicolumn{2}{|r|}{ Computer Addiction } \\
\hline Wasming on punctuation (11) & \multicolumn{2}{|c|}{$\begin{array}{l}\text { Computers nowadays deeply penetrate into our } \\
\text { daily life and we can't do with it even for a minute. There } \\
\text { is a common phenomenon that many students are } \\
\text { intrigued by playing computers. }\end{array}$} \\
\hline Expanded analysis (10) & \multirow{4}{*}{\multicolumn{2}{|c|}{$\begin{array}{l}\text { It is bad for us to spend much time in playing } \\
\text { computers. To start with, excessive addiction to } \\
\text { computers may exert a negative impact on our health } \\
\text { Instead of taking exercise in our spare time, we may be } \\
\text { obsessed with the various contents on it. Furthermore } \\
\text { indulging in computer may isolate us from the social } \\
\text { circles. Since we can chat with the virtual friends via } \\
\text { computers, we may not bother to communicate with } \\
\text { families or friends around us. For a long time many } \\
\text { people would like to type their ideas on the computer } \\
\text { rather than conceive of how to do. }\end{array}$}} \\
\hline Leaming tips (3) & & \\
\hline Prep. mistake (1) & & \\
\hline \multirow[t]{3}{*}{ Sentence mistake (1) } & & \\
\hline & \multicolumn{2}{|c|}{$\begin{array}{l}\text { In my opinions, we have a better to do something } \\
\text { interesting, instead of playing computers. We can have a } \\
\text { short trip with our friends. We should take part in } \\
\text { activities that is good for us. In conclusion, as the } \\
\text { product of the high technology, computer really } \\
\text { promotes our life. Nevertheless, we should not spend too } \\
\text { much time on it at the expense of savoring our good life. }\end{array}$} \\
\hline & Words: 198, submit & commenting (0) browsing (8) \\
\hline
\end{tabular}

Fig. 1. Assessing Results

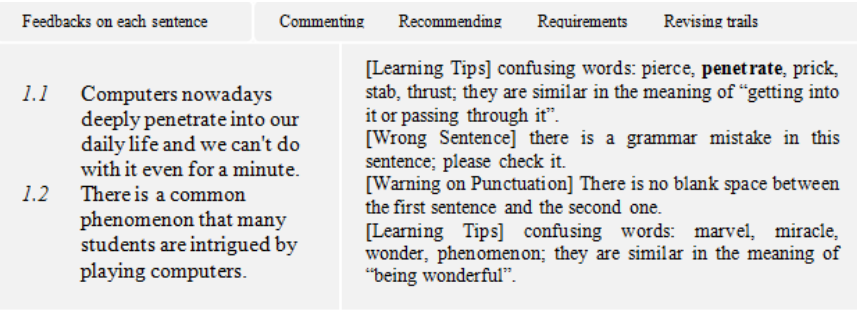

Fig. 2. Feedback on Each Sentence

When students rewrite their compositions, the system will record their revising trails in detail as shown in Fig. 1. In this figure, teachers see their rewriting times is 7 in left corner, highest score 85.5 and the lowest score 31.5 in left head of this figure. After computer scoring and feedback, teachers can give their feedback by clicking the "commenting button" since this system has the function of commenting form teachers, which makes traditional teacher feedback possible and we need to exert its full effects. Meanwhile, this system provides other technology for operation of "Peer Feedback", "Good Composition Sharing" and "Forum", which is significant for peers' writing.

The automated scoring system has another strength: teacher and student can give "feedback on each sentence", "feedback on a paragraph", these strong points with the function of "peer feedback" and "forum" making feedback more directed and targeted by people after the automated scoring system rates submitted compositions from six aspects of "content", "text structure", "sentences", "collocation", "vocabulary and fluency". "Feedback on each sentence" include hints on "wrong sentence", "spelling mistake", "Chinglish", "learning from the model", "possible revision", "nice phrases", "statistics of collocation", "grammar checking" and so on. Students can revise their writing according to these hints and submit their drafts, then reviewing teacher feedback and peer feedback and rewriting. Therefore, teacher feedback is a great help for students' active and independent writing, this platform of automated scoring system with teacher feedback is more suitable and popular among Chinese students. Students also benefit a lot from online feedback to improve their more autonomy in learning and do more langue practice, so do their fellow students in peer feedback session. Because the automated scoring system will analyze the highlight points and eye-catching sentences in part of "feedback on each sentence", even giving more examples for students to learn as shown in Fig 3. Here the phrase "addicted to" is taken as a useful expression and another example is illustrated, which helps students and peers do autonomy learning. Another feedback named "expanded analysis" points out the phrase "surf ...internet" is used 577 times in the standard corpus, providing synonyms "browse internet", "surf net", "surf cyberspace" for students to learn and practice.

[Highlight Points] addicted to: to become dependent on something, which is a useful expression. $A$

She finally understood the disadvantages of being addicted to video games.

good error-reporting

[Expanded Analysis] The phrase "surf ...internet" appears 577 times in the standard corpus.

See Also: browse internet ${ }^{188}$, surf net ${ }^{18}$, surf cyberspace ${ }^{4}$ good error-reporting

Fig. 3. Highlight Points \& Expanded Analysis

But this system itself faces some challenges in several parts. Firstly, it rates essays from the aspect of language only. Secondly, it can't assess essays on the aspect of content and check whether the essay is on or off the topic. A composition can get high score only by wonderful sentences even it is irrelevant to the topic. Thirdly, the system points out the sentence is maybe Chinglish but it can't give a right version for revising. What's worse, it can't point out grammar mistakes and proper collocation as shown in Fig. 4, this sentence from student is quite in Chinese thinking and wrong in grammar. But this system failed to discover it and provide the right feedback for revising. What's more, it sometimes gives no proper "learning tips" shown in Fig. 2, which indicates that "confusing words: marvel, miracle, wonder, phenomenon; they are similar in the meaning of "being wonderful'." Actually, "phenomenon" is something that is observed to happen or exist; and here in the sentence1.2, it is right in expression and collocation, so it is unnecessary and not suitable to give that "learning tips". Fourthly, analyzing the text organization and structure is also unsatisfactory. All 
these shortcomings need to be solved by teachers and peers for the time being.

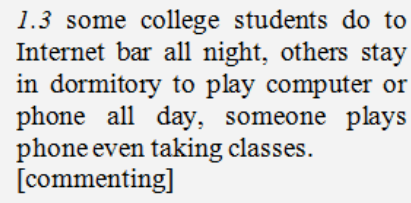
Internet bar all night, others stay in dormitory to play computer or phone all day, someone plays phone even taking classes. [commenting]

[Waming on Sentence] sentences are connected by conjunction. $\Downarrow$

[Waming on Article] "in dormitory to" here is possibly wrong in use of article. There is no article used before a countable noun. $₫$ "play...computer" appears 25 times in the standard corpus. $\unrhd$ [Expanded Analysis] The phrase "take...class" appears 25 times in the standard corpus. $\otimes$ [Expanded Analysis] The phrase

Fig. 4. Improper Learning Tips

\section{Negative And Positive EfFects of EACH FeEdBACK}

In L1 writing research, Knoblauch and Brannon[9] contrasted various types of teacher feedback (e.g. oral vs. written, explicit vs. implicit, positive vs. negative), concluding that none of these feedback modes had much impact on subsequent student writing. Purves[10] labeled teacher responses as strictly mechanical, unhelpful and confusing. According to Connors and Lunsford[11], 300 teachers' feedback on 3,000 student essays are concluded as "a large number of short, careless, exhausted or insensitive comments". In L2 writing, the best-known research conducted by Zamel[12] criticized the behaviors of teachers: "ESL writing teachers misread student texts, are inconsistent in their reactions, make arbitrary corrections, write contradictory comments, provide vague prescriptions, impose abstract rules and standards, respond to texts as fixed and final products, and rarely make content-specific comments or offer specific strategies for revising the text." However, studies following Cohen's [13] research [14][15][16] reported more positive results: The students in general were happy with the feedback they received from teachers. Zhang[17] noted that ESL students greatly valued teacher feedback. M. Yang et al.[18] aimed at examining students at a Chinese university, "teacher feedback was more likely to be adopted and led to greater improvements in the writing". Some research[14] studied students how to deal with teacher feedback, and the results were encouraging: The students utilized various resources to deal with teacher feedback by either thinking about it and trying to make corrections by themselves or going to outside sources like instructors, friends, grammar books or dictionaries[19].

In process-oriented writing approach, there are still some arguments of practicing peer feedback and research results on the effects of peer feedback have been also mixed and even conflicting. Leki[20] noted that "peer feedback tend to focus on 'surface errors' instead of semantic or textual ones and that peer feedback does not facilitate revision. Cognitively speaking, peer feedback can "enhance a sense of audience, raise learners' awareness of their own strengths and weaknesses, encourage collaborative learning, and foster ownership of text''[21]. Chaudron[22] found peer feedback activities enhanced students' communicative power by encouraging them to express and negotiate their ideas.

Online feedback is proved to be effective in improving students writing skill and arousing their interest[23]. But computer is still a computer, mechanic, inflexible and impersonal. language users are people and it changes as time going by. As is discussed in part 2, online feedback from automated scoring system fail to be effective in students' writing from macro-level of text.

In a word, each type of feedback has its strengths and weak points, so what we should do is to find a good way to exert its advantages fully.

\section{SOME USEFul SUGGESTIONS}

Online feedback has its weakness, but its strong functions do solve some realistic problems in writing instruction. And feedback play an important role and are effective in improving students' writing. Some suggestions on incorporation of three feedback are as follows:

First, the best writing instruction should be online feedback from automated scoring system first, then peer feedback for students' drafts is followed by teacher feedback from different aspects to provide comments and suggestions. The incorporation of three feedback in three steps can ensure the positive effects of each feedback and benefits teachers and students. To some extent, students are forced to assess and comment on peers' writing in peer feedback sessions, which in turn can improve their more autonomy in learning, exercising their critical thinking, providing more language practice, building much confidence, and developing their own language skills and cooperative skills.

Second, the writing teacher can focus on giving concrete suggestions on the improvements of the macro-level of text organization, content and structures. While peer students may focus on micro-level of vocabulary and grammar to propose some complementary feedback for the online feedback to help peer students be aware of their wrong points and correct them if necessary, since some students do not know how to revise it according to the online feedback and the feedback from computer is not always right and reliable.

Third, all these steps can be operated online by computer, because Chinese Juku correcting system assisted feedback of three types, although the system itself only gives online feedback. Computer can't tailor writing methods to help individuals and put forward directed guidance and suggestions. It needs people to help specifically and intelligently and teacher and student can work on it, their feedback worthy of consideration and raising revision and improvement.

\section{CONCLUSION}

From the above discussion, we can say that teacher feedback, peer feedback and online feedback can be incorporated in English writing instruction, since they are effective, which were proved by many researchers, and they have many respective merits. What's more, the latter two feedback can reduce teacher's much burden in teaching of writing especially in the large class of Chinese college English. Therefore, by training for peer feedback activities before the application of it, students can trust more in the usefulness of peer feedback and act on it as what the teacher expects. What's clear is that peer feedback and online feedback are not a substitute but a complementary factor to teacher feedback. Teacher feedback's role still can't be replaced in Chinese 
context. In this way, feedback, from computer and people, online and offline, are more comprehensive, reasonable and acceptable.

\section{REFERENCES}

[1] Hyland, K., "Second Language Writing" Cambridge: Cambridge University Press, 2003.

[2] Hyland, K., "Providing productive feedback," ELT Journal, 44(4), 1990, pp. 279-285.

[3] Badger, R. \& White, G. "A process genre approach to teaching writing," ELT Journal, 54(2), 2000, pp. 153-160.

[4] Hu, G., "Potential cultural resistance to pedagogical imports: The case of communicative language teaching in China," Language, Culture and Curriculum, 15(2), 2002, pp. 93-105.

[5] Mangelsdorf, K. "Peer reviews in the ESL composition classroom: What do the students think?" ELT Journal,46(3), 1992, pp. 274-284.

[6] Keh, C.L. "Feedback in the writing process: a model and methods for implementation," ELT Journal, 44(4), 1990, pp. 294- 304.

[7] Gu Chenghua, Wang Li, "An Empirical Study of College English Writing Teaching Based on Juku Correcting Network," Journal of Yangzhou university(higher Education Study Edition), Vol.16 No.4, 2012, pp. 92-96(in Chinese).

[8] Jiang Yan, Ma Wuli, “Artificial Intelligent System of English Writing Instruction in China: Success and Chanllege---Take Juku Correcting System," E-education Research, vol.243 No.7, 2013, pp. 76-81(in Chinese).

[9] Knoblauch, C. \& Brannon, L. "Teacher commentary on student writing: The state of the Art.," Freshman English News, 10, 1981, pp.1-4.

[10] Purves, A. "The teacher as reader: An anatomy," College English, 1984, pp. 259-265.
[11] Connors, R. \& Lunsford, A. "Teachers' rhetorical comments on student papers," College Composition and Communication, 44, 1993, pp. 200223.

[12] Zamel, V. "Responding to student writing," TESOL Quarterly, 19(1), 1985, pp. 79-101.

[13] Cohen, A. D. "Student processing of feedback on their compositions," In A. Wenden \& J. Rubin(Eds.), Learner Strategies in Language Learning . London: Prentice hall. 1987, pp. 57-69.

[14] Cohen, A. D. \& Cavalcanti, M.C. "Feedback on compositions: Teacher and student verbal reports," In B. Kroll (Ed.), Second Language Writing: Research Insights for the Classroom. Cambridge:CUP. 1990, pp. 155177.

[15] Connor, U., \& Asenavage, K. "Peer response groups in ESL writing classes: How much impact on revision?" Journal of Second language Writing, 3, 1994, pp. 257-276.

[16] Paulus, T. M., "The effect of peer and teacher feedback on student writing," Journal of Second Language Writing, 8(3), 1999, pp. 265-289.

[17] Zhang, S. "Reexamining the affective advantage of peer feedback in the ESL writing class," Journal of Second Language Writing, 4, 1995, pp. 209-222.

[18] Yang, M., Richard, B. \& Yu, Z. "A Comparative study of peer and teacher feedback in a Chinese EFL writing class," Journal of second language writing, 15, 2006, pp. 179-200.

[19] Ferris, D. R. "Students reactions to teacher response in multi-draft composition classrooms," TESOL Quarterly, 29(1), 1995, pp. 33-53.

[20] Leki, I. "Potential problems with peer responding in ESL writing classes," CATESOL Journal, 3, 1990, pp. 5-17.

[21] Tsui, A. \& Ng, M. "Do secondary L2 writers benefit from peer comments?" Journal of Second Language Writing, 9(2), 2000, pp. 147170.

[22] Chaudron, C. "Evaluating Writing: Effects of Feedback on Revision.," RELC Journal, 15, 1984, pp. 1-14

[23] He Xuliang, "Reliability and validity of the Assessment by the Pigaiwang on CollegeStudents' Writing," modern educational technology, Vol.23 N0.5, 2013, pp. 64-67(in Chinese). 